\title{
COMBINED EFFECTS OF BODY SIZE, FOOD CONCENTRATION AND SEASON ON THE PHYSIOLOGY OF MYTILUS EDULIS
}

\author{
J. WIDDOWS \\ Institute for Marine Environmental Research, Prospect Place, The Hoe, Plymouth PL1 3 DH
}

(Figs. 1-5)

\begin{abstract}
Multivariate experiments are used to study the effects of body size, food concentration, and season on the oxygen consumption, ammonia excretion, food assimilation efficiency and filtration rate of Mytilus edulis adults. Food concentrations and season affect both the intercept and the slope of the allometric equation describing oxygen uptake as a function of body size. Multiple regression and response surface techniques are used to describe and illustrate the complex relationship between metabolic rate, ration, season and the body size of $M$. edulis. Filtration rate has a relatively low weight exponent $\left(b=0.3^{8}\right)$ and the intercept for the allometric equation is not significantly affected by food concentration, season or acclimation temperatures between 5 and $20^{\circ} \mathrm{C}$. Food assimilation efficiency declines exponentially with increasing food concentration and is dependent on body size at high food levels. The rate of ammonia excretion shows a similar seasonal cycle to that of oxygen consumption. They are both minimal in the autumn/winter and reach a maximum in the spring/summer.
\end{abstract}

\section{INTRODUCTION}

The majority of studies of the physiological ecology of organisms have been concerned with changing a single environmental variable at a time, but more information on the relationships between biological responses and environmental factors would be provided by experimental techniques that emulate the multi-dimensional character of the natural environment.

Experimental designs employing many variables simultaneously have several advantages over a single factor approach: $(a)$ it is possible to obtain a broader understanding of the effects of each factor over the different conditions generated by variations in the other factors; $(b)$ the wide range of factor combinations provides a more reliable basis for making predictions that will be valid in a variety of circumstances, and $(c)$ it provides information on the extent of interactions between variables that are not independent of one another.

In the present study, multivariate experiments have been used to investigate some physiological processes in Mytilus edulis L. The objectives were (a) to measure the adaptive responses of some physiological processes to combinations of levels of environmental factors; $(b)$ to develop multiple regression equations and associated response surfaces that will describe the responses of Mytilus edulis to a wide range of environmental conditions, and $(c)$ to demonstrate ways in which some physiological measurements may be used to quantify the degree of stress experienced under a variety of conditions ranging from near-optimal, through sub-lethal to lethal.

In this, the first of two papers, multivariate experiments were used to study the effects 
of body size, food concentration and season (independent variables) on the oxygen consumption, ammonia excretion, food assimilation efficiency and filtration rate (dependent variables) of Mytilus edulis adults. The second paper is concerned with the integration of these individual physiological responses into indices of stress (Bayne, 1975).

\section{MATERIALS AND METHODS}

\section{Experimental methods}

Mussels were collected at low-water spring tides from a population in the Lynher estuary, a tributary of the River Tamar in the south west of England. They were maintained in an aquarium with recirculating sea water at a salinity of $32.5 \%$.

The experimental design provided for the feeding of temperature-adapted groups of mussels of different body size, at four food ( = ration) levels and at the seasonal ambient temperature for 2-3 weeks in February $\left(5^{\circ} \mathrm{C}\right)$, April $\left(10^{\circ} \mathrm{C}\right)$, June $\left(15^{\circ} \mathrm{C}\right)$, August $\left(20^{\circ} \mathrm{C}\right)$ and November $\left(10^{\circ} \mathrm{C}\right)$. In July, animals were also maintained at $25^{\circ} \mathrm{C}$, which was above the maximum summer sea-water temperature and near the upper lethal temperature for Mytilus edulis. The complexity and size of the experimental design was reduced by confounding acclimation temperature and season, because previous studies (Widdows \& Bayne, 1971; Widdows, 1973 $a, b$ ) have shown that Mytilus edulis acclimates its metabolic and feeding rates to temperatures from 5 to $20^{\circ} \mathrm{C}$.

At each seasonal acclimation temperature, four groups of 30 individuals, each ranging in size from 2 to $8 \mathrm{~cm}$ in length and from 100 to $3000 \mathrm{mg}$ in dry body weight, were maintained in separate tanks and fed at different ration levels. One group, described for convenience as ZR (or zero ration), was starved for 5 weeks by passing the inflow water through a filter of $2 \mu \mathrm{m}$ porosity. Each of the other three groups was fed at a different food level, described here as LR (low ration), MR (medium ration) and HR (high ration) respectively. They were fed for 2-3 weeks with the diatom Phaeodactylum tricornutum at the following concentrations:

$$
\begin{aligned}
& \text { LR: } 4 \times 10^{3} \text { cells ml }^{-1} \text { or } 0.28 \mathrm{mg} \text { dry matter } \mathrm{l}^{-1} \text {, }
\end{aligned}
$$

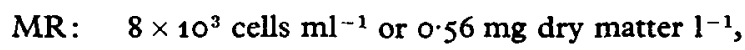

$$
\begin{aligned}
& \text { HR: } 20 \times 10^{3} \text { cells } \mathrm{ml}^{-1} \text { or } 1.4 \mathrm{mg} \text { dry matter } 1^{-1} \text {. }
\end{aligned}
$$

The ration levels chosen were not equally spaced because the feeding and metabolic responses of Mytilus edulis have been shown (Thompson \& Bayne, 1974) to be most sensitive to changes in food concentrations at the lower ration levels. More information was therefore required at food concentrations near the maintenance ration than at higher ration levels.

Phaeodactylum tricornutum was chosen as a food source for several reasons : $(a)$ it is easily grown in monoculture; $(b)$ it is a common and often dominant estuarine phytoplankton species (Tenore, Browne \& Chesney, 1974), and (c) the cell has a high inorganic content $(25 \%)$, compared with other algal species, and more closely approximates the high inorganic content of particulate matter in estuarine and coastal waters. The high inorganic content also means that the 'Conover ratio' (Conover, 1966) provides a reliable estimate of true assimilation efficiency as any small uptake of inorganic matter from the ingested food will not have a marked effect on the ash-free to total dry-weight ratio of the faeces.

Following the period of acclimation of animals to a specific ration level and temperature, their rates of oxygen consumption, filtration and ammonia excretion, and the assimilation efficiency, were determined over a size range of individuals for each ration/seasonal ambient temperature condition. The rate of oxygen consumption was measured by isolating the animal in an experimental flask for periods of $45-60 \mathrm{~min}$ and recording the decline in oxygen tension with a Radiometer oxygen meter (Bayne, 1971). The filtration rate, defined as the volume of water cleared of particles per unit time, was estimated in a flow system $\left(70 \mathrm{ml} \mathrm{min}{ }^{-1}\right)$ by monitoring the removal of Phaeodactylum as the water passed through the experimental chambers containing individual mussels (Widdows \& Bayne, 1971; Widdows, 1973a). These animals were then held in this flow system for $24 \mathrm{~h}$ to enable sufficient faeces to be deposited for determining assimilation efficiency.

The efficiency of assimilation of ingested food was estimated by measuring the dry weight and ash-free dry weight of cells from the Phaeodactylum cultures and faecal pellets pooled from 
individuals of similar sizes. The ash-free to dry-weight ratios of the food and faeces were then used in calculating the Conover ratio (Conover, 1966):

$$
\text { assimilation efficiency }=\frac{F-E}{(1-E) F} \times 100,
$$

where $F=$ ash-free dry weight :dry-weight ratio in the ingested food, and $E=$ ash-free dry weight: dry-weight ratio in the faeces.

The rate of ammonia excretion of mussels adapted to each season/ration condition was determined by placing eight animals, equally distributed over the experimental size range, in individual trays containing $200 \mathrm{ml}$ of membrane filtered sea water. Animals were then incubated for a period of $4 \mathrm{~h}$ at the appropriate seasonal acclimation temperature. Controls of filtered sea water from the same batch, but with no animals, were incubated at the same time. The samples and controls were then analysed in duplicate for ammonia, using the phenol-hypochlorite method of Solorzano (1969); the difference, representing the amount of ammonia excreted, was expressed as $\mu \mathrm{g}$ ammonia nitrogen per animal per hour.

Twelve animals were sampled from each season/ration combination for the determination of the gonad index. A piece of mantle tissue was examined microscopically as described by Bayne $\&$ Thompson (1970) and the gonad development classified into stages ranging from o for fully spawned animals to 3 for animals containing fully mature gametes. This simple index, however, does not enable the partially spawned animals to be distinguished from the fully ripe animals in the prespawning stage. In a separate study (Salkeld, personal communication) mussels collected from the Lynher population at intervals throughout the year were sectioned ( $7 \mu \mathrm{m}$ thick), stained and examined microscopically. The gametogenic cycle was then assessed in terms of the percentage of the mantle occupied by gametes, thereby enabling partial spawning to be assessed.

At the end of each experiment all animals were removed from their shells and dried to constant weight at $90^{\circ} \mathrm{C}$, so that each measured rate could be related to dry flesh weight.

\section{Analysis of data}

The data sets derived from these multivariate experiments are too extensive to be published in their basic form. (Data sets are on file and available from the author.) In the initial data analysis, the relationships between body weight and physiological rates, such as oxygen consumption, filtration rate and ammonia excretion, were described for each experimental condition by the simple allometric equation :

$$
Y=a X^{b},
$$

where $Y=$ the physiological rate (dependent variable), $X=$ the dry flesh weight (independent variable) and $\log (a)$ and $b$ are the intercept and slope of the $\log Y v \cdot \log X$ regression respectively. The individual regression lines for each rate function were then compared by analysis of covariance to test first whether the slopes were significantly different and, if not, whether the intercepts were significantly different. When there was no significant difference in slopes, a common regression coefficient was calculated, which was then used to recalculate the intercepts. This form of analysis and presentation is adequate when the response of the organism to several factors is of a relatively simple nature. But when the relationship between a dependent variable (e.g. physiological response) and two independent variables is of a more complex nature, the data is most concisely presented in the form of a response surface (Alderdice, 1972). In this and a subsequent paper (Widdows, 1978), the situation is further complicated by relating a dependent variable to three independent variables. This relationship can be presented in the form of a series of response surfaces, each representing a level of the third independent variable. However, multiple regression equations provide a more concise and coherent method of describing the relationships between a dependent variable and three or more independent variables. In addition, the multiple regression equations and response surfaces can be used for interpolating between data points.

Multiple regression equations were obtained by the method of orthogonal polynomials using the ASCOP statistical package at the SRC Atlas Computer Laboratory, Didcot, Berkshire. Higherdegree terms in the polynomial equations were added until a satisfactory fit to the data was obtained and the addition of further terms did not significantly improve the degree of fit. The criterion used to determine a satisfactory description was the ratio of the sum of squares due to 
regression, to the total sum of squares. No 'goodness of fit' test was possible on the data because the independent variable (weight) was continuous and therefore unreplicated. Analysis of variance of the multiple regression relation provided an estimate of the proportion of the total variance explained by the equation employed. The unexplained component would be due both to experimental error and to failure of the equation to fit the surface exactly. The latter source of error is likely to be small as the surface always demonstrated a close fit to the individual regression lines.

Table 1. Regression analysis of rates of oxygen consumption $\left(\mathrm{ml} \mathrm{O}_{2} h^{-1}\right)$ by Mytilus edulis of different dry tissue weight $(\mathrm{g})$ for each combination of ration level and seasonal ambient temperature

\section{Condition}

(seasonal ambient temperature and ration level)

February

$5^{\circ} \mathrm{HR}$
$5^{\circ} \mathrm{MR}$
$5^{\circ} \mathrm{LR}$
$5^{\circ} \mathrm{ZR}$
April

$10^{\circ} \mathrm{HR}$

$10^{\circ} \mathrm{MR} \quad 23$

$10^{\circ} \mathrm{LR}$

$10^{\circ} \mathrm{ZR}$

June

$15^{\circ} \mathrm{HR}$

$15^{\circ} \mathrm{MR}$

$15^{\circ} \mathrm{LR}$

$15^{\circ} \mathrm{ZR}$

August

$20^{\circ} \mathrm{HR}$

$20^{\circ} \mathrm{MR}$

$20^{\circ} \mathrm{LR}$

$20^{\circ} \mathrm{ZR}$

July

$25^{\circ} \mathrm{HR}$

$25^{\circ} \mathrm{MR}$

$25^{\circ} \mathrm{LR}$

$25^{\circ} \mathrm{ZR}$

November

$10^{\circ} \mathrm{HR}$

$10^{\circ} \mathrm{MR}$

$10^{\circ} \mathrm{LR}$

$10^{\circ} \mathrm{ZR}$

$$
\begin{array}{cc}
\text { No. of } & \text { Intercept } \\
\text { animals } & a \pm \text { s.D. }
\end{array}
$$

$$
\begin{aligned}
& 0.382 \pm 0.021 \\
& 0.245 \pm 0.013 \\
& 0.241 \pm 0.012 \\
& 0.149 \pm 0.010
\end{aligned}
$$

$0.348 \pm 0.017$

$0.272 \pm 0.016$

$0.279 \pm 0.017$

$0.312 \pm 0.015$

$0.399 \pm 0.010$

$0.367 \pm 0.017$

$0.299 \pm 0.015$

$0.367 \pm 0.020$

$0.465 \pm 0.021$

$0.391 \pm 0.019$

$0.414 \pm 0.018$

$0.385 \pm 0.020$

$0.607 \pm 0.035$

$0.629 \pm 0.040$

$0.549 \pm 0.054$

$0.542 \pm 0.045$

$0.282 \pm 0.016$

$0.213 \pm 0.012$

$0.214 \pm 0.011$

$0.205 \pm 0.013$

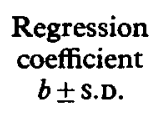

$0.725 \pm 0.050$

$0.739 \pm 0.057$

$0.670 \pm 0.043$

$0.723 \pm 0.093$

$0.498 \pm 0.044$

$0.619 \pm 0.055$

$0.619 \pm 0.071$

$0.729 \pm 0.106$

$0.455 \pm 0.035$

$0.756 \pm 0.058$

$0.702 \pm 0.057$

$0.861 \pm 0.078$

$0.376 \pm 0.043$

$0.594 \pm 0.118$

$0.596 \pm 0.064$

$0.612 \pm 0.044$

$0.384 \pm 0.071$

$0.616 \pm 0.051$

$0.582 \pm 0.067$

$0.568 \pm 0.065$

$0.574 \pm 0.067$

$0.551 \pm 0.067$

$0.666 \pm 0.059$

$0.639 \pm 0.066$

\section{Correlation coefficient}

$r$

0.95

0.94

0.96

0.88

0.92

0.89

0.88

0.84

0.95

0.94

0.93

0.92

0.88

0.78

0.91

0.95

0.77

0.95

0.89

0.92

0.88

0.87

0.93

0.90
Recalculated
intercept
$(b=0.65)$

0.363

0.234

0.237

0.146

0.299

0.284

0.313

0.361

0.327

0.353

0.391

0.420

0.394

0.619

0.604

0.613

0.291

0.225

0.213

0.207

The multiple regression equations in this study and Widdows (1978) have been used primarily for descriptive purposes, enabling the dependent variable to be computed readily for specified values of the independent variables. Response surfaces were generated from each multiple regression equation by constructing a detailed matrix representing the surface and then plotting specified isopleths on a line-printer to create the contoured response surface.

\section{RESULTS \\ Oxygen consumption}

The relationship between the rate of oxygen consumption and body weight can be described by the equation

$$
\dot{V}_{\mathrm{O}_{2}}=a W^{b},
$$


where $\dot{V}_{\mathrm{O}_{2}}=$ rate of oxygen uptake $\left(\mathrm{ml} \mathrm{O}_{2} \mathrm{~h}^{-1}\right), W=$ body weight $(\mathrm{g})$, and $a$ and $b$ are the intercept and slope respectively. This equation can be written in its linear form as

$$
\log _{10} \dot{V}_{\mathrm{O}_{2}}=\log _{10} a+b \log _{10} W .
$$

The regression of log oxygen consumption against log body weight was calculated for each ration/seasonal ambient temperature condition (Table 1). Analysis of covariance showed that the regression coefficients of all but four regression lines were not signifi-

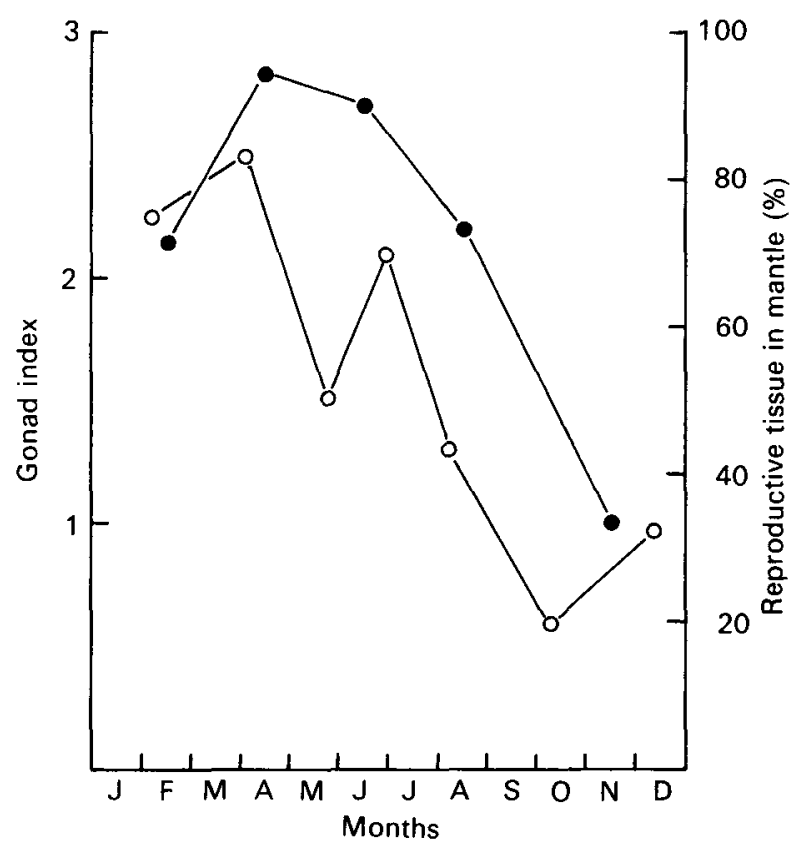

Fig. 1. The gametogenic cycle of Mytilus edulis. Experimental animals; $O$, field sample.

cantly different from one another at $P=0.05$, and therefore a common regression coefficient was determined for these 20 data sets. Using the common $b$ value $(0.65)$, the values for the constant a were then calculated. The four experimental conditions with significantly lower $(P=0.01)$ regression coefficients were (1) high ration at $10^{\circ} \mathrm{C}$ in April, or 10HR $(b=0.5)$; (2) $15 \mathrm{HR}(b=0.46) ;(3) 20 \mathrm{HR}(b=0.38)$ and (4) $25 \mathrm{HR}$ $(b=0.38)$.

The food concentration available to an animal therefore affected both the slope and the intercept of the regression equations of oxygen consumption against body weight. However, these effects were not consistent throughout the year. During the summer period from April to August, when the animals contained mature gametes (Fig. 1), the reduction of the regression coefficients was caused by a higher rate of metabolism by smaller individuals, rather than a depressed rate by larger animals. All animals fed at the high ration level ( 20000 cells $\mathrm{ml}^{-1}$ ), except those at $25 \mathrm{HR}$, had a rate of oxygen uptake significantly higher than those of animals fed at the lower ration levels. At food levels 
below the highest ration, the rate of oxygen consumption was relatively independent of food concentration. An exception to this was the reduced metabolic rate of unfed animals in January at $5 \mathrm{ZR}$.

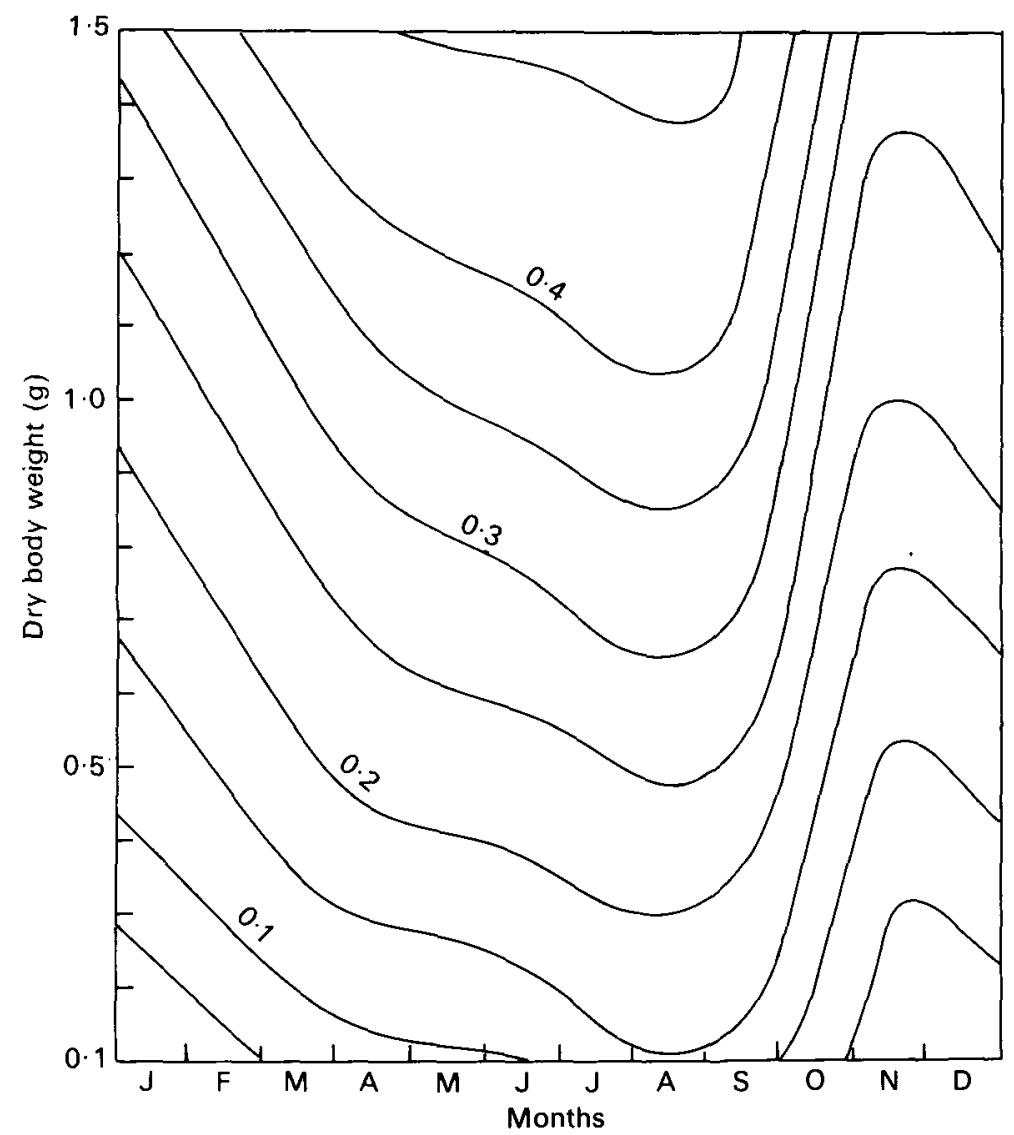

Fig. 2. Isopleths of oxygen consumption $\left(\mathrm{ml} \mathrm{O}_{2} \mathrm{~h}^{-1}\right)$ by Mytilus edulis as a function of body size and season (ration level $0.56 \mathrm{mg} \mathrm{l}^{-1}$ ).

The complex relationship between oxygen consumption, body weight, ration and seasonal acclimation temperature as described by the individual regression equations (Table 1) is difficult to interpret except by multiple regression analysis. The following multiple regression equation describes the rate of oxygen consumption of Mytilus edulis as a function of body size, ration and season:

$$
\begin{aligned}
\text { metabolic rate }= & 0.056737+(0.18786) W-(0.0225176) W^{2}-(0.0114243) T \\
& -\left(0.389148 \times 10^{-3}\right) T^{2}+\left(0.312911 \times 10^{-3}\right) T^{3}-\left(0.267093 \times 10^{-4}\right) T^{4} \\
& +\left(0.951495 \times 10^{-6}\right) T^{5}-\left(0.154842 \times 10^{-7}\right) T^{6}+\left(0.945608 \times 10^{-10}\right) T^{7} \\
& -(0.0414322) R+(0.0339086) R^{2}+(0.0054635) W T+(0.12471) W R \\
& -(0.00010403) W T^{2}-(0.0424804) R W^{2},
\end{aligned}
$$


where metabolic rate is expressed as $\mathrm{ml} \mathrm{O}_{2} \mathrm{~h}^{-1}, W=$ dry tissue weight $(0 \cdot 1-2 \cdot 0 \mathrm{~g})$, $T=$ time (0-52 weeks) and $R=$ ration $\left(0-1.5 \mathrm{mg} \mathrm{l}^{-1}\right)$.

This equation explains $82 \%$ of the total variance in the experimental data (520 data points). Part of the response surface derived from this equation for a food concentration of $0.56 \mathrm{mg} \mathrm{l}^{-1}$ is presented in Fig. 2.

The main factor which appeared to affect the rate of oxygen consumption was the seasonal cycle of reproductive condition (Fig. 1). The rate of oxygen uptake by a $1 \mathrm{~g}$ animal was at a maximum $\left(0.39 \mathrm{ml} \mathrm{O}_{2} \mathrm{~h}^{-1}\right)$ in late spring and summer when the animals were fully mature, and then declined to a minimum $\left(0.21 \mathrm{ml} \mathrm{O}_{2} \mathrm{~h}^{-1}\right)$ in the autumn and early winter during the period of gametogenic quiescence (Fig. 2).

\section{Filtration rate}

Linear regressions of $\log$ filtration rate against log body weight were calculated for each ration/seasonal temperature condition (Table 2). The regression coefficients were low and variable. Two factors could have contributed to this: $(a)$ the size range extended

Table 2. Regression analysis of filtration rate (litres $h^{-1}$ ) against dry tissue weight $(g)$ for each combination of ration level and seasonal ambient temperature

Condition

(seasonal ambient temperature and ration level)

February

$5^{\circ} \mathrm{HR}$

$5^{\circ} \mathrm{MR}$

$5^{\circ} \mathrm{LR}$

April

$10^{\circ} \mathrm{HR}$

$10^{\circ} \mathrm{MR}$

$10^{\circ} \mathrm{LR}$

June

$15^{\circ} \mathrm{HR}$

$15^{\circ} \mathrm{MR}$

$15^{\circ} \mathrm{LR}$

August

$20^{\circ} \mathrm{HR}$

$20^{\circ} \mathrm{MR}$

$20^{\circ} \mathrm{LR}$

July

$25^{\circ} \mathrm{HR}$

$25^{\circ} \mathrm{MR}$

$25^{\circ} \mathrm{LR}$

November

$10^{\circ} \mathrm{HR}$

$10^{\circ} \mathrm{MR}$

$10^{\circ} \mathrm{LR}$

$\begin{array}{ccc}\text { No. of } & \text { Intercept } & \begin{array}{c}\text { Regression } \\ \text { coefficient } \\ \text { animals }\end{array} \\ a \pm \text { S.D. } & b \pm \text { S.D. }\end{array}$

$2.083 \pm 0.121$
$1.901 \pm 0.134$
$1.894 \pm 0.188$

$2 \cdot 511 \pm 0.257$
$2.789 \pm 0.221$
$2.028 \pm 0.149$

$2.380 \pm 0.151$
$2 \cdot 318 \pm 0.052$
$2 \cdot 317 \pm 0.124$
$2 \cdot 189 \pm 0.127$
$2.066 \pm 0.108$
$2.024 \pm 0.105$
$1.534 \pm 0.151$
$1.615 \pm 0.201$
$1.375 \pm 0.138$
$2.002 \pm 0.127$
$1.734 \pm 0.122$
$1.882 \pm 0.141$
$0.266 \pm 0.057$

$0.145 \pm 0.075$

$0.165 \pm 0.083$

$0.279 \pm 0.095$

$0.507 \pm 0.077$

$0.096 \pm 0.082$

$0.313 \pm 0.048$

$0.200 \pm 0.031$

$0.172 \pm 0.078$

$0.328 \pm 0.055$

$0.234 \pm 0.055$

$0.179 \pm 0.066$

$0.080 \pm 0.132$

$0.208 \pm 0.119$

$0.025 \pm 0.114$

$0.235 \pm 0.073$

$0.018 \pm 0.034$

$0.355 \pm 0.088$

\section{Correlation \\ coefficient \\ $\boldsymbol{r}$}

\subsection{3 \\ 0.39}

0.41

0.54

0.82

0.25

0.81

0.82

0.40

0.79

0.71

0.52

0.14

0.40

$0 \cdot 10$

0.57

0.05

0.67
Recalculated intercept $(b=0.38)$

over the upper size classes for the species (from 0.1 to $2.0 \mathrm{~g}$ ), and it is in the larger animals that filtration rate appears to become more independent of body size (Winter, 1973; Thompson \& Bayne, 1974); and (b) the natural individual variation in filtration rate. Therefore, a more detailed study of the relationship between filtration rate and weight was carried out at $15^{\circ} \mathrm{MR}$. This involved 50 individuals ranging from 15 to 
$2400 \mathrm{mg}$ dry weight. The relationship between filtration rate and body size is described by the following equation:

$$
\text { filtration rate }=2.65 \times W^{0.38} \quad(r=0.90),
$$

where filtration rate is expressed in litre $\mathrm{h}^{-1}$ and body weight $(W)$ in grammes dry weight.

This weight exponent was similar to that previously recorded for Mytilus edulis by Thompson \& Bayne (1974) and Winter (1973). Using the regression coefficient of $b=0.38$, the intercepts of the regression lines have been recalculated (Table 2) and are plotted in Fig. 3.

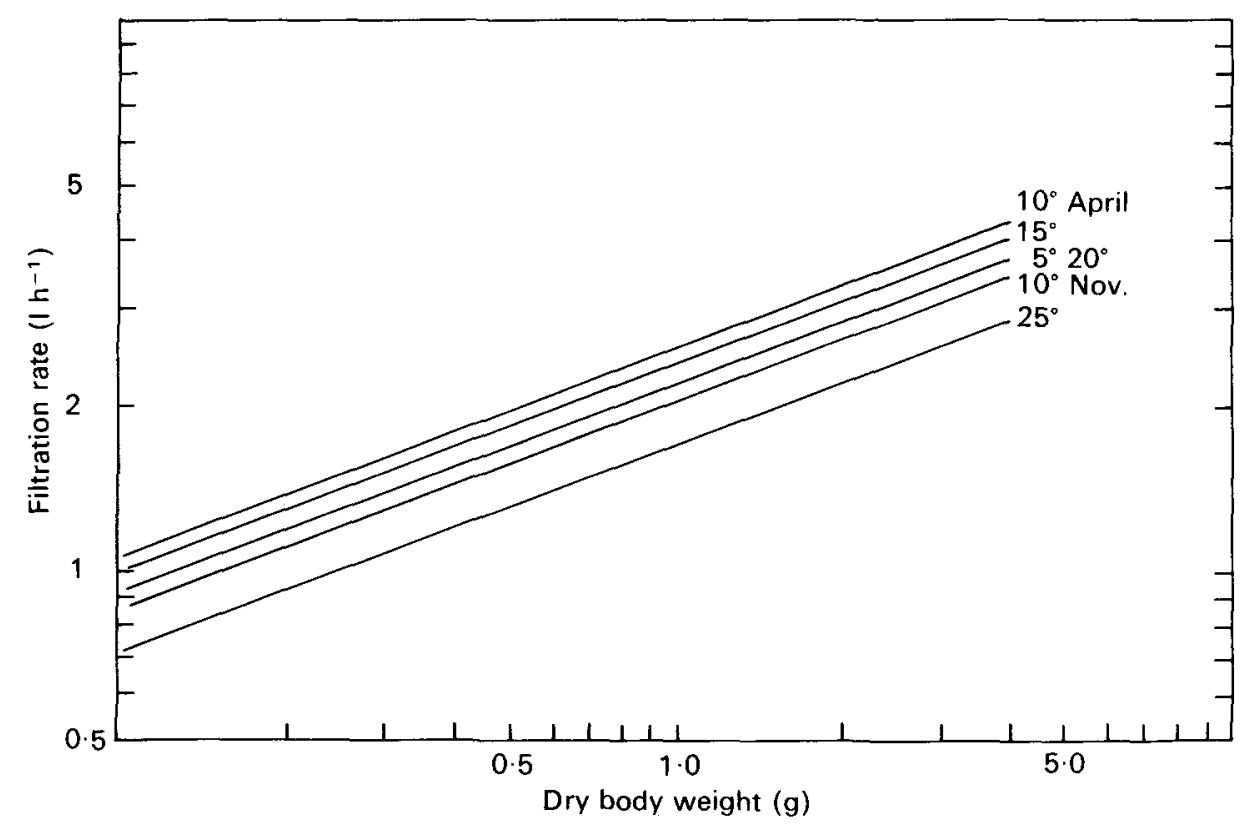

Fig. 3. The relationship between filtration rate and dry tissue weight of Mytilus edulis at different seasonal acclimation temperatures $\left({ }^{\circ} \mathrm{C}\right)$.

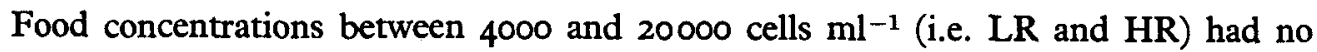
significant effect on the filtration rate of $M$. edulis (Table 2). Therefore the regression of filtration rate against body weight is represented by a single regression line for each seasonal acclimation temperature (Fig. 3)

The feeding activity of $M$. edulis was also maintained at a relatively constant level throughout the year as a result of the acclimation of filtration rate to temperatures between 5 and $20^{\circ} \mathrm{C}$ (Fig. 4). There was a maximum filtration rate at $10^{\circ} \mathrm{C}$ (spring), but the rate at this temperature was not statistically significantly different from the rates recorded at 5,15 and $20^{\circ} \mathrm{C}$. At $25^{\circ} \mathrm{C}$, however, the filtration rate was significantly depressed (Fig. 4).

A multiple regression equation or response surface describing the relationship between filtration rate, body weight, ration and seasonal acclimation temperature has not 
been presented, as the response forms a simple flat surface that can be readily interpreted and interpolated from the linear regression lines.

\section{Assimilation efficiency}

The efficiency of assimilation of ingested algal cells was dependent on body weight and food concentration. There was no significant effect of acclimation temperature on assimilation efficiency.

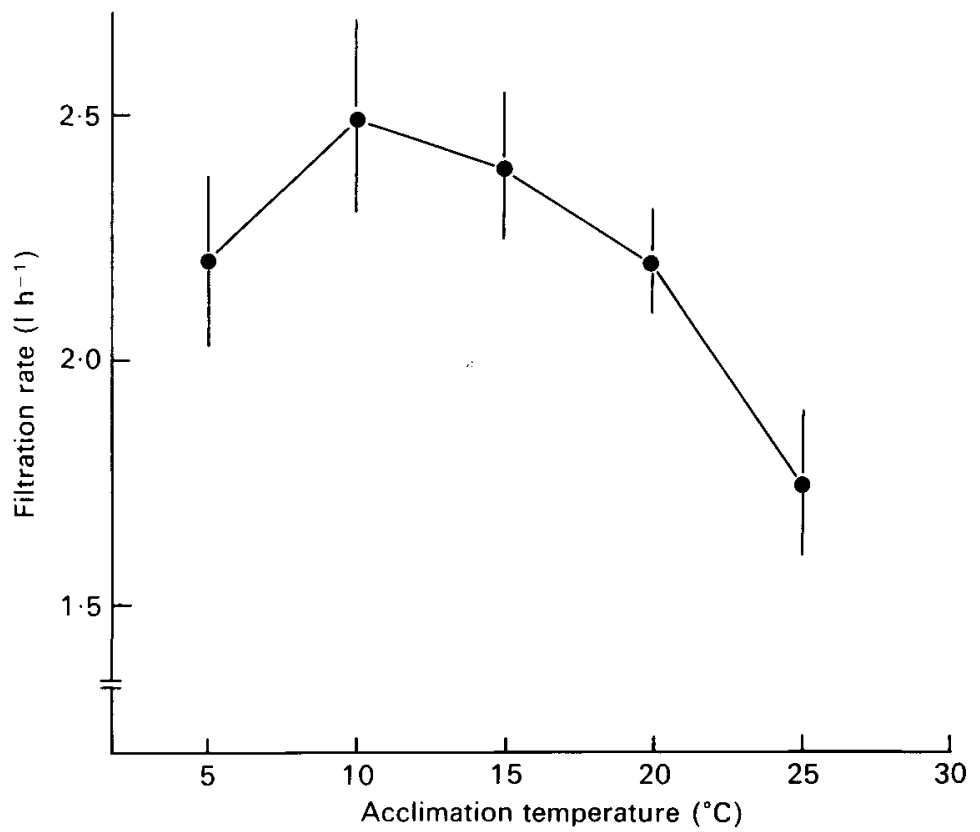

Fig. 4. The effect of acclimation temperature on the filtration rate of Mytilus edulis (1 g dry weight). Mean \pm S.D.

The decline in the assimilation efficiency of $M$. edulis with increasing food concentration (Fig. 5) was best described by exponential equations (Table 3). The effect of body size on the efficiency of assimilating ingested food has been shown by dividing animals into four size classes (approximately $0.2,0.5,0.9$ and $1.5 \mathrm{~g}$ dry weight). Fig. 5 shows that there was no measurable effect of body size at the low cell concentrations, where assimilation efficiency was high $(75 \%)$. However, as food concentration increased and assimilation efficiency declined, the effect of body size became more pronounced. At the highest cell concentration (20000 cells $\mathrm{ml}^{-1}$ ), the largest animals $(1.5 \mathrm{~g})$ had an assimilation efficiency of $45 \%$ compared with a lower efficiency of $24 \%$ in the smallest individuals $(0.2 \mathrm{~g})$ studied. This difference was significant at $P=0.01$.

\section{Ammonia excretion}

Regressions of $\log _{10}$ ammonia nitrogen excretion against $\log _{10}$ dry flesh weight were calculated for each ration/seasonal ambient temperature condition (Table 4). There 
was high variability in the slopes of the regression lines, due in part to the small sample size. No biological significance could be attached to any high or low $b$ value as the changes did not follow a consistent pattern. Therefore the relationship between ammonia excretion and body weight was not analysed further. However, the intercept of

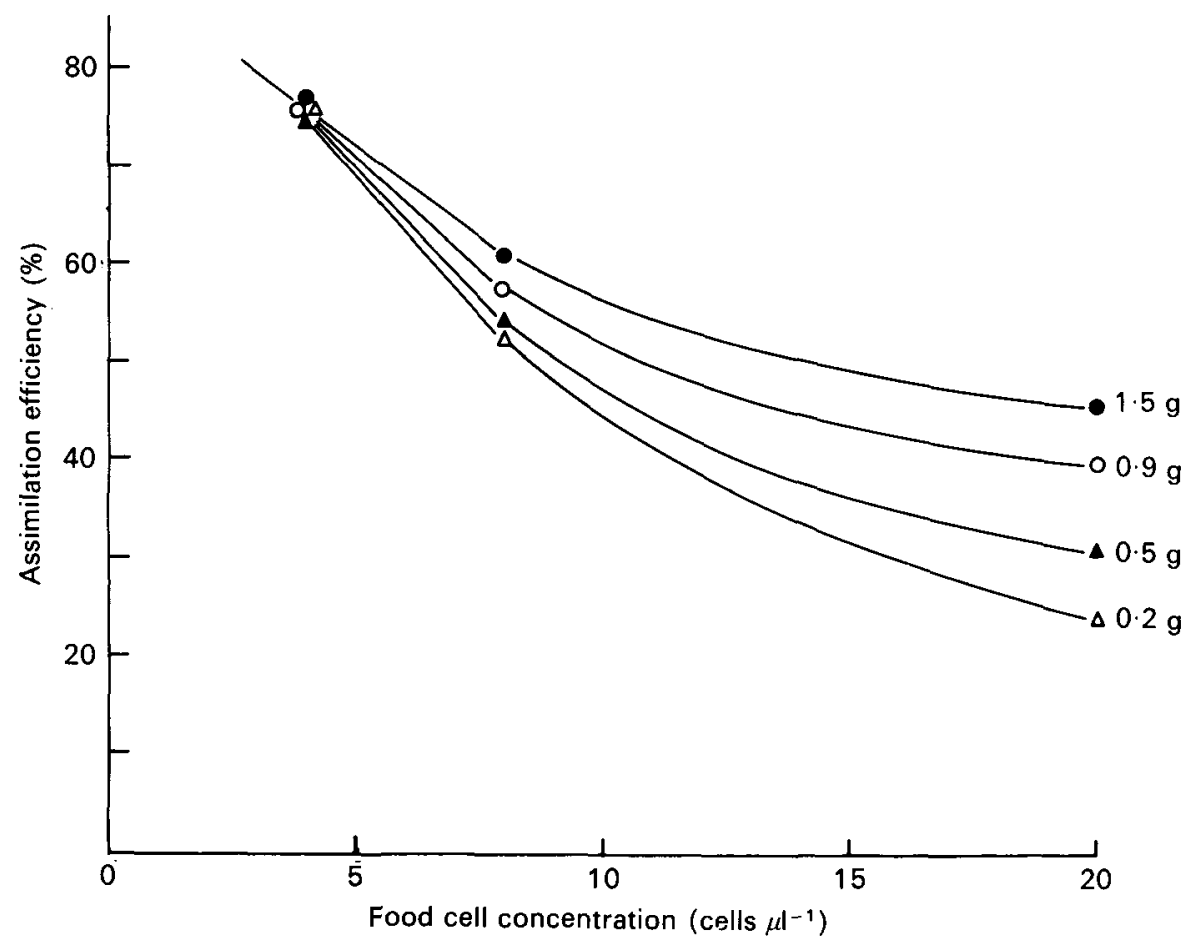

Fig. 5. The effect of food cell concentration and body size on the food assimilation efficiency of Mytilus edulis.

Table 3. Equations describing the effect of food concentration on the assimilation efficiency of Mytilus edulis of different body weights

Body weight ( $(\mathrm{g})$

$\begin{array}{lll}0.2 & \text { A.E. }=96.50 F^{-0.088} & (r=0.99) \\ 0.5 & \text { A.E. }=91.42 F^{-0.035} & (r=0.99) \\ 0.9 & \text { A.E. }=88.06 F^{-0.041} & (r=0.98) \\ 1.5 & \text { A.E. }=85.96 F^{-0.033} & (r=0.98) \\ \text { A.E. }=\% \text { assimilation efficiency. } & \\ \left.F=\text { food concentration (cells } \mu \mathrm{l}^{-1}\right) .\end{array}$

the regression equation represented the rate of ammonia excretion by a $1 \mathrm{~g}$ animal, which was close to the mean body weight for each group of animals. Therefore the $a$ value was used to illustrate the effect of ration and seasonal acclimation temperature on the ammonia excretion rate by $M$. edulis.

In April $\left(10^{\circ} \mathrm{C}\right)$ and August $\left(20^{\circ} \mathrm{C}\right)$ the rates of ammonia excretion increased as the food concentration declined. In June $\left(15^{\circ} \mathrm{C}\right)$ the excretion rates had increased and were 
independent of ration; there was also a high rate of ammonia excretion at the upper temperature of $25^{\circ} \mathrm{C}$. During the autumn $\left(10^{\circ} \mathrm{C}\right)$ and winter $\left(5^{\circ} \mathrm{C}\right)$ the rate of ammonia excretion by $M$. edulis was minimal (approximately $8 \mu \mathrm{g} \mathrm{NH}_{4}-\mathrm{N} \mathrm{g}^{-1} \mathrm{~h}^{-1}$ ).

Table 4. Regression analysis of rates of ammonia excretion $\left(\mu g \mathrm{NH}_{4}-\mathrm{Nh}^{-1}\right)$ against dry tissue weight $(g)$ for each combination of ration level and seasonal ambient temperature

\begin{tabular}{|c|c|c|c|c|}
\hline $\begin{array}{l}\text { Condition } \\
\text { (seasonal ambient } \\
\text { temperature and } \\
\text { ration level) }\end{array}$ & $\begin{array}{c}\text { No. of } \\
\text { animals }\end{array}$ & $\begin{array}{c}\text { Intercept } \\
a \pm \text { s.D. }\end{array}$ & $\begin{array}{c}\text { Regression } \\
\text { coefficient } \\
b \pm \text { S.D. }\end{array}$ & $\begin{array}{c}\text { Correlation } \\
\text { coefficient } \\
r\end{array}$ \\
\hline \multicolumn{5}{|l|}{ February } \\
\hline $5^{\circ} \mathrm{HR}$ & 8 & $8 \cdot 74 \pm 1 \cdot 38$ & $0.67 \pm 0.12$ & 0.91 \\
\hline $5^{\circ} \mathrm{MR}$ & 8 & $7.00 \pm 1.36$ & $0.40 \pm 0.23$ & 0.58 \\
\hline $5^{\circ} \mathrm{LR}$ & 8 & $14 \cdot 60 \pm 2 \cdot 10$ & $0.62 \pm 0.13$ & 0.89 \\
\hline $5^{\circ} \mathrm{ZR}$ & 8 & $8.15 \pm 0.10$ & $0.83 \pm 0.14$ & 0.93 \\
\hline \multicolumn{5}{|l|}{ April } \\
\hline $10^{\circ} \mathrm{HR}$ & 8 & $9.33 \pm 1.68$ & $0.72 \pm 0.57$ & 0.72 \\
\hline $10^{\circ} \mathrm{MR}$ & 8 & $7 \cdot 76 \pm 1.67$ & $0.49 \pm 0.26$ & 0.62 \\
\hline $10^{\circ} \mathrm{LR}$ & 8 & $19 \cdot 19 \pm 1 \cdot 73$ & $0.30 \pm 0.11$ & 0.75 \\
\hline $10^{\circ} \mathrm{ZR}$ & 8 & $24.99 \pm 1.67$ & $0.55 \pm 0.08$ & 0.94 \\
\hline \multicolumn{5}{|l|}{ June } \\
\hline $15^{\circ} \mathrm{HR}$ & 8 & $21.84 \pm 2.65$ & $0.61 \pm 0.17$ & 0.83 \\
\hline $15^{\circ} \mathrm{MR}$ & 8 & $23.26 \pm 3.07$ & $0.97 \pm 0.18$ & 0.92 \\
\hline $15^{\circ} \mathrm{LR}$ & 8 & $14.91 \pm 1.92$ & $0.06 \pm 0.27$ & 0.08 \\
\hline $15^{\circ} \mathrm{ZR}$ & 8 & $24.01 \pm 2.48$ & $1.11 \pm 0.14$ & 0.96 \\
\hline \multicolumn{5}{|l|}{ August } \\
\hline $20^{\circ} \mathrm{HR}$ & 8 & $9.61 \pm 0.81$ & $0.74 \pm 0.08$ & 0.97 \\
\hline $20^{\circ} \mathrm{MR}$ & 8 & $14.79 \pm 1.81$ & $0.69 \pm 0.12$ & 0.92 \\
\hline $20^{\circ} \mathrm{LR}$ & 8 & $25.47 \pm 2.69$ & $0.66 \pm 0.13$ & 0.89 \\
\hline $20^{\circ} \mathrm{ZR}$ & 8 & $20.75 \pm 3.09$ & $0.55 \pm 0.15$ & 0.84 \\
\hline \multicolumn{5}{|l|}{ July } \\
\hline $25^{\circ} \mathrm{HR}$ & 8 & $27 \cdot 11 \pm 3 \cdot 23$ & $0.72 \pm 0.17$ & 0.87 \\
\hline $25^{\circ} \mathrm{MR}$ & 8 & $57.98 \pm 8.91$ & $1.08 \pm 0.18$ & 0.93 \\
\hline $25^{\circ} \mathrm{LR}$ & 8 & $25 \cdot 16 \pm 3.92$ & $0.69 \pm 0.15$ & 0.89 \\
\hline $25^{\circ} \mathrm{ZR}$ & 8 & $45.72 \pm 3.75$ & $0.78 \pm 0.07$ & 0.98 \\
\hline \multicolumn{5}{|l|}{ November } \\
\hline $10^{\circ} \mathrm{HR}$ & 8 & $9 \cdot 96 \pm 1.33$ & $0.83 \pm 2.25$ & 0.82 \\
\hline $10^{\circ} \mathrm{MR}$ & 8 & $7.42 \pm 1 \cdot 17$ & $0.40 \pm 0.16$ & 0.73 \\
\hline $10^{\circ} \mathrm{LR}$ & 8 & $8.24 \pm 0.78$ & $1.52 \pm 0.19$ & 0.95 \\
\hline $10^{\circ} \mathrm{ZR}$ & 8 & $8 \cdot 54 \pm 1 \cdot 31$ & $0.22 \pm 0.17$ & 0.45 \\
\hline
\end{tabular}

\section{DISCUSSION}

A feature of Mytilus edulis and other boreal bivalves is their marked seasonal cycle of gametogenic activity linked with the storage and utilization of reserve materials in the body (Bayne \& Thompson, 1970; Gabbott \& Bayne, 1973). This reproductive cycle exerts a major influence on physiological processes such as oxygen consumption and ammonia excretion (Widdows \& Bayne, 1971; Bayne, 1973, 1976), while other processes such as filtration remain relatively constant throughout the year.

The response surface, used here to illustrate the relationship between oxygen consumption, season and body size, demonstrates the marked seasonal cycle in the respiration rate of $M$. edulis (Fig. 2). Metabolic rate appears to be directly correlated with the gametogenic cycle, which in turn is conditioned by seasonal sea-water temperature. 
However, temperature has been shown to have little direct effect on oxygen consumption by $M$. edulis due to the processes of thermal acclimation that compensate for temperature change (Widdows \& Bayne, 1971; Bayne, Thompson \& Widdows, 1973). The weightspecific respiration rate is high in the spring and summer, when the gonad cortains developing and mature gametes and forms up to $35 \%$ of the total body weight. During the autumn and early winter there is a period of gametogenic quiescence, which is accompanied by a significantly lower metabolic rate. The form of the seasonal metabolic and reproductive cycles varies from population to population depending upon annual temperature cycles and latitude (Seed, 1976; Bayne, Thompson \& Widdows, 1976).

The influence of body size on the rate of oxygen consumption is described by the regression coefficient or the weight exponent $(b)$ in the regression equation:

$$
\dot{V}_{\mathrm{O}_{2}}=a W^{b} .
$$

The biological significance of the exponent has been the subject of considerable speculation (Zeuthen, 1947, 1953; Hemmingsen, 1950, 1960; Von Bertalanffy, 1957). In bivalves there is much intraspecific and interspecific variation in the exponent $b$; values range from 0.16 to 1.02 , although the majority fall within the range 0.4 to 0.9 (reviewed by Bayne, Thompson \& Widdows, 1976). It is therefore incorrect to refer to oxygen consumption in bivalves as being proportional to either surface area $(b=0.67)$ or body weight $(b=1 \cdot 0)$. Environmental factors responsible for changes in the weight exponent are generally unknown due to a lack of information on the experimental conditions used in the various studies. The work of Krüger (1960) and Newell \& Roy (1973) suggests that factors such as temperature and season can influence the value of $b$.

In the present study the rate of oxygen consumption has a common slope of 0.65 when $M$. edulis is adapted to most experimental combinations of ration and seasonal ambient temperature, and only under four conditions (10HR-April, 15HR-June, $20 \mathrm{HR}$-August, and $25 \mathrm{HR}$ ) were the $b$ values significantly lower $(0.50,0.46,0.38$ and 0.38 respectively). A weight exponent of $b=0.65$ is similar to that described for $M$. edulis in earlier studies (Krüger, 1960; Bayne, 1973; Bayne, Thompson \& Widdows, 1973; Vahl, 1973). The four lower weight exponents are generally below those obtained

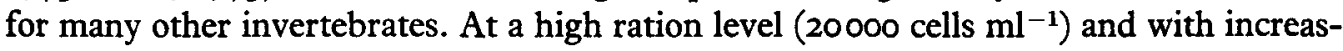
ing acclimation temperature, the regression slopes are reduced as a result of an increase in the rate of oxygen consumption by smaller individuals. This increased energy requirement of small animals may be associated with an 'over-loading' of the filter feeding mechanism and digestive system at high cell concentrations, proportional to body size. Three points support this hypothesis. Firstly, the smaller animals filter proportionately more food than the larger animals. Secondly, although no pseudofaeces were observed at the time of faeces collection from smaller animals, pseudofaeces are known to be produced by $M$. edulis when fed at cell concentrations above approximately 20000 cells $\mathrm{ml}^{-1}$ (Thompson \& Bayne, 1972; Foster-Smith, 1975), and unpublished observations suggest that this threshold concentration for pseudofaecal production is reduced with declining body size, occurring at a concentration of approximately $8000 \mathrm{cells} \mathrm{ml}^{-1}$ for a $20 \mathrm{mg}$ animal. Thirdly, assimilation efficiency of animals fed at the high ration levels also declines with decreasing body size (Fig. 5), indicating that in the smaller animals 
proportionately larger amounts of filtered food are moved through the digestive system undigested and ejected as intestinal faeces. However, this does not explain the absence of a reduced weight exponent for oxygen consumption at high ration levels in the autumn and winter.

The effect of ration and, in particular, starvation, on the metabolic rate of M. edulis appears to vary depending upon the season and the physiological condition of the animal. In winter (February, $5^{\circ} \mathrm{C}$ ), when the mussels do not contain mature gametes and there is less food available in the natural environment, the rate of oxygen consumption of starved animals is reduced to a 'standard rate' as shown in previous studies (Widdows \& Bayne, 1971; Bayne, 1973; Widdows, 1973 $a$, $b$; Bayne, Thompson \& Widdows, 1973; Thompson \& Bayne, 1972, 1974). However, at all other times of the year there is no significant reduction in the rate of oxygen uptake following 5 weeks of starvation. During this period (April-September), the presence of mature gametes in the mantle may inhibit the reduction of activity and metabolism of $M$. edulis to a standard level. Gabbott \& Bayne (1973) recorded a similar response in an earlier work and suggested that there may be a mechanism that prevents a reduction in metabolic rate as long as reserves are available in the body tissues to meet the energy demand of gametogenesis. The present study shows that there is always a small but significant effect of ration on the rate of oxygen consumption by $M$. edulis. The metabolic rate of animals fed at the high ration level (HR) is consistently higher than the rate of those maintained at the lower ration levels (MR and LR), but there is generally no significant difference between the medium and low ration levels.

The filtration rate of $M$. edulis is maintained relatively constant throughout the year independent of physiological condition and temperature. Long-term independence of temperature is achieved by complete thermal acclimation between 5 and $20^{\circ} \mathrm{C}$ (Widdows \& Bayne, 1971; Widdows, 1973a). The breakdown in the thermal acclimation of filtration rate above $20^{\circ} \mathrm{C}$ results in a reduced filtration rate at $25^{\circ} \mathrm{C}$ and a cessation of activity at $28^{\circ} \mathrm{C}$ (Widdows, 1976). The results of this study show that there is no effect of food cell concentration on the filtration rate of $M$. edulis up to $20 \times 10^{3} \mathrm{cells}^{-1}$. This independence of cell concentration is similar to that described by Thompson \& Bayne (1974) and by Foster-Smith (1975) over a wider range of concentrations $\left(50 \times 10^{3}\right.$ to $700 \times 10^{6}$ cells $\mathrm{l}^{-1}$ ). However, Winter (1973) has recorded a decline in the filtration rate of $M$. edulis with increasing cell concentrations between 10 and $40 \times 10^{6}$ cells $1^{-1}$. Schulte (1975) also demonstrated a decline, but this was significant only at high concentrations between $10^{7}$ and $10^{8}$ cells $1^{-1}$. These differences are not easily explained. The relationship between cell concentration and filtration rate may perhaps be dependent on the phytoplankton species and the nature of the particular matter.

The effect of body size on the filtration rate of bivalves has been the subject of considerable debate in the literature. Winter (1973) demonstrated that the different weight exponents were probably a result of the size range over which filtration rate was determined. In those studies that examined the relationship between filtration rate and body size over a size range of small individuals, the weight exponents were relatively high ( $b=0.74$ : Winter, 1973; $b=0.60:$ Vahl, 1973), whereas the low weight exponent of 0.38 described in this paper is comparable to values found in other studies that included 
large animals in the size range (Willemsen, 1952; Theede, 1963; Winter, 1973; Thompson \& Bayne, 1974).

The assimilation of ingested food by Mytilus is not affected either by seasonal changes in the physiological condition of the animals or by acclimation temperature. In response to increasing cell concentrations, the assimilation efficiency declines exponentially (see also Thompson \& Bayne, 1972, 1974) and at concentrations greater than $4 \times 10^{3}$ cells $\mathrm{ml}^{-1}$ there is an interaction between cell concentration and body size.

Smaller animals have a lower assimilation efficiency than larger individuals and the difference with respect to size increases with increasing cell concentration, becoming statistically significant at the high ration level. In an earlier study, Thompson \& Bayne (1974) showed no significant effect of body size on assimilation efficiency at cell concentrations below 10000 cells $\mathrm{ml}^{-1}$. However, their results did indicate that smaller individuals had slightly lower assimilation efficiencies and the difference would presumably have become more significant at higher cell concentrations. The lower assimilation efficiency in small animals at high cell concentrations is probably a result of their relatively higher feeding and ingestion rates. This would increase the proportion of undigested food (intestinal faeces) in the total faeces and may also cause production of pseudofaeces at lower cell concentrations in small animals.

Ammonia forms the major excretory end-product of protein and amino-acid catabolism in Mytilus edulis (Bayne, Widdows \& Thompson, 1976) and therefore the rate of ammonia-nitrogen excretion may be regarded as reflecting the rate of protein catabolism. The seasonal cycle in the rate of ammonia excretion is similar to that described previously by Bayne (1973) and appears to be related to the physiological and reproductive condition of the animal. The rates of oxygen consumption and ammonia excretion both follow a similar seasonal cycle. Ammonia excretion is at a minimum in the autumn and early winter during the period of gametogenic quiescence and increases to maximum values in the spring and summer when the animal is maintaining mature gametes in the mantle. This probably reflects a marked seasonal shift from a reliance on carbohydrate as the main energy reserve in the autumn to a greater reliance on protein as the main reserve in the spring (Gabbott \& Bayne, 1973).

At high temperature $\left(25^{\circ} \mathrm{C}\right)$, near the upper limit of the environmental and physiological temperature range for $M$. edulis, there is a marked increase in the rates of metabolism and ammonia excretion, which indicates a greater degree of protein catabolism in order to meet the increased metabolic energy demand.

The effect of ration on the rate of ammonia excretion is only apparent in the spring $\left(10^{\circ} \mathrm{C}\right)$ and summer $\left(20^{\circ} \mathrm{C}\right)$. At this time of year there is a greater reliance on protein as an energy reserve, but this can be reduced by increasing the ration. In June $\left(15^{\circ} \mathrm{C}\right)$, however, the animals are in poor condition after spawning and protein utilization is not reduced at high ration levels.

This multivariate study has shown the utility of multivariate experiments and response surface techniques in describing the physiological response of organisms to complex environments. It has both confirmed and summarized many of the conclusions drawn from previous investigations (for review, see Bayne, 1976). In addition, the experiments have demonstrated $(a)$ an altered weight exponent for the allometric equation 
describing the relationship between oxygen consumption and body size at high food levels and high temperatures, and $(b)$ the effect of size on the food assimilation efficiency at high ration levels. However, the effect of factors on the rate of individual physiological processes, although informative, does not provide sufficient understanding of the 'whole organism' respunse to the total environmental stimulus. This is achieved by means of physiological integrations, which bring together related processes in order to provide a fundamental measure of an organism's physiological condition and the degree of stress to which it is subjected (Bayne, Widdows \& Thompson, 1976). In a second paper, physiological integrations and stress indices derived from these multivariate experiments will be described and presented in the form of response surfaces.

I am grateful to Dr B. L. Bayne for valuable discussions and critically reading the manuscript. I am also indebted to Mr P. J. Radford for guidance and assistance in the analysis of the data and to $\mathrm{Mr}$ C. M. Worrall for help with the measurement of excretion rates. This work forms part of the estuarine and nearshore research programme of the Institute for Marine Environmental Research, a component of the Natural Environment Research Council. It was supported by a NERC fellowship and was also commissioned in part by the Department of the Environment (contract no. DGR 480/47).

\section{REFERENCES}

Alderdice, D. F., 1972. Factor combinations. In Marine Ecology, vol. 1, part 3 (ed. O. Kinne), pp. 1659-1722. New York: Wiley-Interscience.

BAYNE, B. L., 1971. Oxygen consumption by three species of lamellibranch mollusc in declining ambient oxygen tension. Comparative Biochemistry and Physiology, 40A, 955-970.

BAYNe, B. L., 1973. Physiological changes in Mytilus edulis L. induced by temperature and nutritive stress. Fournal of the Marine Biological Association of the United Kingdom, 53, 39-58.

BAYNE, B. L., 1975. Aspects of physiological condition in Mytilus edulis (L), with special reference to the effects of oxygen tension and salinity. In Proceedings of the 9 th European Marine Biology Symposium (ed. H. Barnes), pp. 213-238. Aberdeen: Aberdeen University Press.

Bayne, B. L., 1976. Marine Mussels: Their Ecology and Physiology. 494 pp. Cambridge : Cambridge University Press.

BAyne, B. L. \& Thompson, R. J., 1970. Some physiological consequences of keeping Mytilus edulis in the Laboratory. Helgoländer wissenschaftliche Meeresuntersuchungen, 20, 526-552.

BAYNE, B. L., ThOMPSON, R. J. \& WIDDows, J., 1973. Some effects of temperature and food on the rate of oxygen consumption by Mytilus edulis L. In Effects of Temperature on Ectothermal Organisms (ed. W. Wieser), pp. 181-193, Berlin: Springer-Verlag.

Bayne, B. L., Thompson, R. J. \& WIDdows, J., 1976. Physiology: I. In Marine Mussels: Their Ecology and Physiology (ed. B. L. Bayne), pp. 121-206. Cambridge: Cambridge University Press.

Bayne, B. L., Widdows, J. \& Thompson, R. J., 1976. Physiological integrations. In Marine Mussels: Their Ecology and Physiology (ed. B. L. Bayne), pp. 261-291. Cambridge: Cambridge University Press.

BERTALANFFY, L. vON, 1957. Quantitative laws in metabolism and growth. Quarterly Review of Biology, 32, 217-231.

CONOVER, R. J., 1966. Assimilation of organic matter by zooplankton. Limnology and Oceanography, 11, 338-354.

FOSTER-SMITH, R. L., 1975. The effect of concentration of suspension on the filtration rates and pseudofaecal production for Mytilus edulis L., Cerastoderma edule L. and Venerupis pullastra (Montagu). Fournal of Experimental Marine Biology and Ecology, 17, 1-22.

GaBbotT, P. A. \& BAYNe, B. L., 1973. Biochemical effects of temperature and nutritive stress on Mytilus edulis L. Fournal of the Marine Biological Association of the United Kingdom, 53, 269286. 
Hemmingsen, A. M., 1950. The relation of standard (basal) energy metabolism to total fresh weight of living organisms. Report of the Steno Memorial Hospital and the Nordisk Insulinlaboratorium, 4, 7-58.

Hemmingsen, A. M., 1960. Energy metabolism as related to body size and respiratory surfaces and its evolution. Report of the Steno Memorial Hospital and the Nordisk Insulinlaboratorium, 9, 7-110.

KRÜGER, F., 1960. Zue Frage der Grössenabhängigkeit des Sauerstoffverbrauchs von Mytilus edulis L. Helgoländer wissenschaftliche Meeresuntersuchungen, 7, 125-148.

Newell, R. C. \& Roy, A., 1973. A statistical model relating the oxygen consumption of a mollusk (Littorina littorea) to activity, body size and environmental condition. Physiological Zoölogy, 46, 253-275.

SCHULTE, E. H., 1975. Influence of algal concentration and temperature on the filtration rate of Mytilus edulis. Marine Biology, 30, 331-341.

Seed, R., 1976. Ecology. In Marine Mussels: Their Ecology and Physiology (ed. B. L. Bayne), pp. 13-65. Cambridge: Cambridge University Press.

Solorzano, L., 1969. Determination of ammonia in natural waters by the phenol-hypochlorite method. Limnology and Oceanography, 14, 799-801.

Tenore, K. R., Browne, M. G. \& Chesney, E. J., 1974. Polyspecies aquaculture systems: The detrital trophic level. Fournal of Marine Research, 32, 426-432.

ThEede, H., 1963. Experimentelle Untersuchungen über die Filtrations leistung der Miesmuschel Mytilus edulis L. Kieler Meeresforschungen, 19, 20-41.

Thompson, R. J. \& BAYNE, B. L., 1972. Active metabolism associated with feeding in the mussel Mytilus edulis L. Fournal of Experimental Marine Biology and Ecology, 8, 191-212.

Thompson, R. J. \& BAYNE, B. L., 1974. Some relationships between growth, metabolism and food in the mussel, Mytilus edulis. Marine Biology, 27, 317-326.

VAHL, O., 1973. Pumping and oxygen consumption rates of Mytilus edulis L. of different sizes. Ophelia, 12, 45-52.

WIDDOws, J., 1973 $a$. Effect of temperature and food on the heart beat, ventilation rate and oxygen uptake of Mytilus edulis. Marine Biology, 20, 269-276.

WIDDows, J., 1973b. The effects of temperature on the metabolism and activity of Mytilus edulis L. Netherlands fournal of Sea Research, 7, 387-398.

WIDDows, J., 1976. Physiological adaptation of Mytilus edulis to cyclic temperatures. Fournal of Comparative Physiology, 105, 115-128.

WIDDows, J., 1978. Physiological indices of stress in Mytilus edulis L. Fournal of the Marine Biological Association of the United Kingdom, 58, 125-142.

WIDDOWs, J. \& BAYNE, B. L., 1971. Temperature acclimation of Mytilus edulis with reference to its energy budget. Fournal of the Marine Biological Association of the United Kingdom, 51, 827843.

WILLEMSEN, J., 1952. Quantities of water pumped by mussels (Mytilus edulis) and cockles (Cardium edule). Archives neerlandaises de zoologie, 10, 153-160.

WIINTER, J. E., 1973. The filtration rate of Mytilus edulis and its dependence on algal concentration, measured by a continuous automatic recording apparatus. Marine Biology, 22, 317-328.

ZEUTHEN, E., 1947. Body size and metabolic rate in the animal kingdom, with special regard to the marine microfauna. Compte rendu des travaux du Laboratoire de Carlsberg (Serie Chimique), 26, 17-161.

ZeUTHEN, E., 1953. Oxygen uptake as related to body size in organisms. Quarterly Review of Biology, 28, 1-12. 